\title{
Peach palm and cassava wastes as biosorbents of tartrazine yellow dye and their application in industrial effluent
}

\author{
Resíduos do palmito pupunha e da mandioca como biossorvente do corante amarelo tartrazina e \\ sua aplicação em efluente industrial \\ L. N. Santos*; C. E. Porto; M. K. Bulla; V. R. Batistela; B. C. B. Barros \\ Department of Technology, State University of Maringá, 87506-370, Umuarama-PR, Brazil \\ *eng.ambiental.lununes@gmail.com \\ (Recebido em 20 de outubro de 2020; aceito em 15 de maio de 2021)
}

\begin{abstract}
In this study, the wastes from cassava (CAW) and peach palm (PPW) agro-industries were investigated as potential low-cost biosorbents for removing the tartrazine yellow dye (TAR). The by-products were prepared by washing and drying steps and characterized into physicochemical parameters and microstructure. The effects of contact time, $\mathrm{pH}$, dosage and dye concentration were analyzed for the biosorbents in comparison to commercial activated carbon (AC). The biosorbents were applied to the treatment of an effluent from a juice industry containing TAR. Cellulose was the main component of the biosorbents $(31.47-51.20 \mathrm{~g} 100$ $\mathrm{g}^{-1}$ ), which was correlated to the functional groups identified by ATR-FTIR spectra and the materials had a porous surface. The zero point of charge was 3.75 for PPW and 4.60 for CAW. The $\mathrm{pH}$ parameter had a significant effect on the adsorption process, with the maximum values of adsorption being reached at $\mathrm{pH} 2.0$, with removal of $94.7 \%$ for PPW, $74.4 \%$ for CAW and $97.7 \%$ for AC, at the dosage of $7.5 \mathrm{~g} \mathrm{~L}^{-1}$ at $25.0^{\circ} \mathrm{C}$. The adsorption of TAR was fast in the early stages, and at $120 \mathrm{~min}$ the three adsorbents reached the equilibrium. Isotherms of adsorption showed that Langmuir's and Freundlich's models fitted the best to the CAW and PPW experimental data, respectively. The wastes evaluated in this work can be an interesting alternative to TAR adsorption in the industrial effluent without being subjected to chemical treatments.

Keywords: Adsorption, tartrazine dye, wastewater.
\end{abstract}

Neste estudo, os resíduos das agroindústrias de mandioca (CAW) e pupunha (PPW) foram investigados como potenciais biossorventes de baixo custo para a remoção do corante amarelo tartrazina (TAR). Os subprodutos foram preparados pelas etapas de lavagem e secagem e caracterizados quanto aos parâmetros físico-químicos e a microestrutura. Os efeitos do tempo de contato, $\mathrm{pH}$, dosagem e concentração de corante foram analisados para os biossorventes em comparação ao carvão ativado comercial (AC). Os biossorventes foram aplicados no tratamento de um efluente de uma indústria de sucos contendo TAR. A celulose foi o principal componente

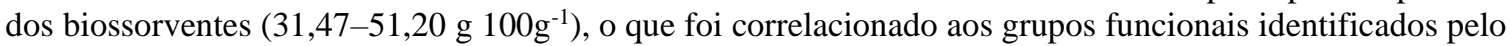
ATR-FTIR, e os materiais apresentaram superfície porosa. O ponto de carga zero foi 3,75 para PPW e 4,60 para CAW. Verificou-se que o parâmetro $\mathrm{pH}$ teve efeito significativo no processo de adsorção, sendo os valores máximos de adsorção atingidos em pH 2,0, com remoção de 94,7\% para PPW, 74,4\% para CAW e $97,7 \%$ para $\mathrm{AC}$, na dosagem de $7,5 \mathrm{~g} \mathrm{~L}^{-1}$ a $25,0^{\circ} \mathrm{C}$. A adsorção da TAR foi rápida nos estágios iniciais e, aos 120 min, os três adsorventes atingiram o equilíbrio. As isotermas de adsorção mostraram que os modelos de Langmuir e Freundlich se ajustaram melhor aos dados experimentais CAW e PPW, respectivamente. Os resíduos avaliados neste trabalho podem ser uma alternativa interessante para adsorção de TAR no efluente industrial sem serem submetidos a tratamentos químicos.

Palavras-chave: Adsorção, corante tartrazina, efluente.

\section{INTRODUTION}

The current population growth, associated with the increased consumption of food products, results in an intensification of the agro-industrial productivity. Producers have been invested in this segment to meet this need, but the industrial yield is not total and a lot of wastes and effluents are generated [1]. In current literature agro-industrial by-products are proposed as sustainable biosorbents alternative to activated carbon, one of the most applied adsorbents in the world [2-8]. However, the high production cost of activated carbon or chemical treatments, restrict the waste application as biosorbents and, in some cases, they are even unfeasible [9]. 
Brazil is the world's third biggest producer of cassava (Manihot esculenta), with an annual production of over 17 million tons [10]. During the industrial processing of the roots, high amounts of fibrous residues, known as cassava bagasse waste (CAW), are generated. It is estimated that for each ton of cassava used in the starch production, about $928 \mathrm{~kg}$ of wet bagasse is generated [11]. Brazil is also considered one of the largest producers and consumers of heart-of-palm (locally known as palmito) in the world, holding for $85 \%$ of the world demand. The peach palm or pupunha palm (Bactris gasipaes) is one of the most cultivated palm trees for obtaining heart-of-palm in the country [12], which is an important alternative to the sustainability of the production chain, because in addition to collaborating with the reduction of predatory exploration of other species, it has a rapid growth and formation of tillers [13]. However, this sector has an estimated waste generation of $80 \%$ from raw material. This peach palm waste (PPW) is characterized as sheaths and stems, which are not used in the processing of the heart-of-palm and present great potential for reuse [14].

One important application of biosorbents is the removal of synthetic dyes characterized by chemical stability, resistance to chemical, physical and biological agents [15] and intense colors even at low concentrations [16]. The presence of these colorants in wastewater directly affects natural aquatic systems, since it decreases the entry of light in the receiving bodies, restricting photosynthesis [10]. Among the synthetic dyes commonly used in food industries, Tartrazine Yellow (TAR; Figure 1) is a colorant belonging to the functional azo-compound group [17].

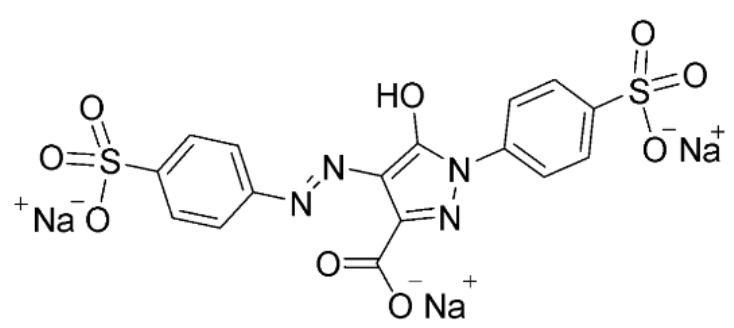

Figure 1: Chemical structure of TAR.

TAR is mainly used for having high stability to oxidation process and heat, color uniformity and relatively low cost [18]. Therefore, the removal of food dyes from liquid effluents, such as TAR, is essential to preserve the quality of water bodies. However, the use of conventional methods of treatment, such as filtration, sedimentation, among others, are not usually efficient in removing this class of pollutants [19].

This work aims to characterize cassava bagasse and peach palm waste and to study their potential in TAR adsorption in comparison with active carbon (AC). After defining the better conditions of adsorption of synthetic dye, the wastes were used to the treatment of juice processing effluent containing TAR. So, it is expected to obtain efficient and low cost biosorbents, to promote sustainable alternatives to agro-industrial wastes and to the treatment of liquid effluents.

\section{MATERIAL AND METHODS}

\subsection{Preparation of biosorbents}

Agro-industries of the state of Paraná/Brazil donated the PPW, obtained from the sheaths discarded in the canning process of heart-of-palm, and the CAW, produced after the starch extraction. Due to the high moisture of the wastes, > 90\% weight/weight (w/w), they were submitted to drying in an oven with forced air circulation (Marconi MA 035) at $90{ }^{\circ} \mathrm{C}$ for $24 \mathrm{~h}$, until reach a final moisture of $10 \% \pm 1 \mathrm{w} / \mathrm{w}$, and they were grounded in knife mill (Solab). The dried materials were washed thoroughly with distilled water to remove impurities that could difficult the adsorption process. Then, the materials were dried again at $90^{\circ} \mathrm{C}$ for $24 \mathrm{~h}$, grounded in a mini bench processor, sieved and standardized to a particle size of $0.15 \mathrm{~mm}$. 


\subsection{Characterization of biosorbents}

The protein, ash, and moisture content of the samples were determined based on the AOAC methods 920.87, 923.03, and 925.09, respectively [20]. Furthermore, the contents of neutral detergent fibers and acid detergent fibers were determined [21] to obtain the contents of cellulose, hemicellulose and lignin [22]. CAW still has starch as one of its major components, which was determined by the enzymatic method AOAC 996 [20], followed by reducing sugars determination [22]. The physicochemical analyzes were performed in triplicate.

The spectra of infrared attenuated total reflection with Fourier transform (ATR-FTIR) were obtained to identify the functional groups in the PPW and CAW biosorbents. For this purpose, the Agilent Cary 630 ATR-FTIR spectrophotometer was used, with a horizontal attenuated total reflectance accessory using a platinum diamond crystal. The spectra were obtained in the range of $650-4000 \mathrm{~cm}^{-1}$, with a resolution of $8 \mathrm{~cm}^{-1}$ and 32 scans.

The evaluation of the biosorbents morphological characteristics was carried out with scanning electron microscopy (SEM), using a QUANTA 250 FEI microscope at a voltage of $12.50 \mathrm{kV}$. The samples were placed in a double-sided tape attached to an aluminum support and metallized with gold and subsequently analyzed at 500x, 1000x and 3000x in magnification.

The $\mathrm{pH}$ at the potential of zero point of charge $\left(\mathrm{pH}_{\mathrm{zpc}}\right)$ of the biosorbents was determined using acid $(\mathrm{HCl})$ and basic solutions $(\mathrm{NaOH})$ in the region of $\mathrm{pH} 2.0$ to 12.0 , by diluting stock solutions of $0.1 \mathrm{~mol} \mathrm{~L}^{-1} \mathrm{HCl}$ or $0.1 \mathrm{~mol} \mathrm{~L}^{-1} \mathrm{NaOH}$. Then, $0.15 \mathrm{~g}$ of sample and $10 \mathrm{~mL}$ of each solution was mixed and stirred in a shaker (Marconi, 830A) at $120 \mathrm{rpm}$ for $24 \mathrm{~h}$ at $25^{\circ} \mathrm{C}$. From the $\Delta \mathrm{pH}\left(\mathrm{pH}_{\text {final }}\right.$ - $\mathrm{pH}_{\text {initial }}$ ) versus $\mathrm{pH}_{\text {initial }}$ graph, the $\mathrm{pH}_{\mathrm{zpc}}$ values were obtained by the $\mathrm{pH}_{\text {initial }}$ corresponding to $\Delta \mathrm{pH}$ equal to zero [23].

\subsection{Adsorption of tartrazine dye}

A stock solution of $1000 \mathrm{mg} \mathrm{L}^{-1}$ of TAR dye was prepared and the different concentrations used were prepared from this solution by dilutions. Based on a previous study [24] the adsorption capacity was evaluated using $20 \mathrm{~mL}$ of TAR solutions in Erlenmeyer flasks of $250 \mathrm{~mL}$, at $25.0^{\circ} \mathrm{C}$ and shaker agitation at $120 \mathrm{rpm}$. After adsorption, the samples were centrifuged (Metroderm) for $60 \mathrm{sec}$ at $3000 \mathrm{rpm}$ and the supernatants were analyzed in a spectrophotometer (Femto, 700 Plus) with monitoring at wavelengths of $428 \mathrm{~nm}$ (analytical) and $800 \mathrm{~nm}$ (baseline). The percentage values of adsorption (\% Ads) were estimated with Eq.1, where the reduction in absorbance at 428 $\mathrm{nm}$ reflects the dye removal.

$$
\text { Ads } \%(428 \mathrm{~nm})=\left(\frac{A s_{\text {initial }}-A s_{\text {final }}}{A b s_{\text {initial }}}\right) \times 100 \%
$$

In which $\mathrm{Abs}_{\text {initial }}$ refers to the absorbance at $\mathrm{t}=0$ and $\mathrm{Abs}_{\text {final }}$, for $\mathrm{t}=2 \mathrm{~h}$.

Commercial activated carbon (AC, Synth) was also studied as a model of adsorbent compound (standard) in the same conditions of the other biosorbents. The AC was used without additional treatment and presented a particle size of 8-16 mesh (1-2 mm). All the adsorption experiments were carried out in triplicate. The adsorption experimenttal process is outlined in the Figure 2. 


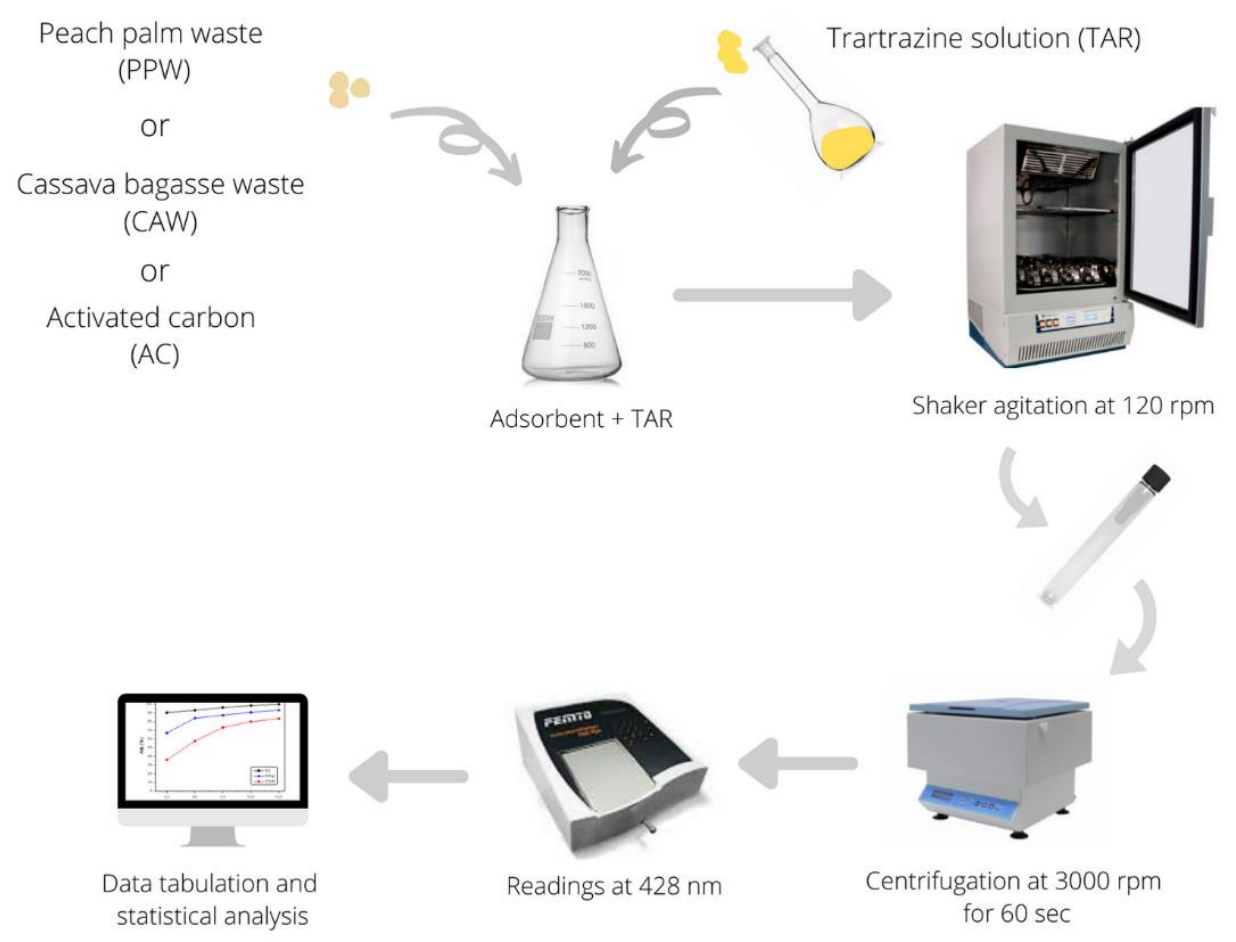

Figure 2: Scheme of the experimental sequence for analysis of adsorption.

\subsubsection{Preliminary conditions of adsorption process}

Kinetic studies were carried out with $20 \mathrm{~mL}$ of a TAR solution of $11.0 \mathrm{mg} \mathrm{L}^{-1}\left(2.1 \times 10^{-5} \mathrm{~mol}\right.$ $\mathrm{L}^{-1}$ ) and $150 \mathrm{mg}$ of adsorbent, resulting in adsorbent dosage of $7.5 \mathrm{~g} \mathrm{~L}^{-1}$. The study of the kinetic effect was aimed to analyze the equilibrium time of adsorption, which was monitored for $180 \mathrm{~min}$, with a fixed $\mathrm{pH}$ of 2.0 at $25^{\circ} \mathrm{C}$.

The $\mathrm{pH}$ study was carried out to determine the medium (acid or basic) in which the adsorption is more intense, so the $\mathrm{pH}$ values varied from 1.0 to 9.0 were evaluated, for $120 \mathrm{~min}$ at $25^{\circ} \mathrm{C}\left(\mathrm{C}_{0}\right.$ : $11 \mathrm{mg} \mathrm{L}^{-1}$, dosage: $\left.7.5 \mathrm{~g} \mathrm{~L}^{-1}\right)$. The initial $\mathrm{pH}$ of the solutions was adjusted with hydrochloric acid $(0.10 \mathrm{M} \mathrm{HCl})$ and sodium hydroxide $(0.10 \mathrm{M} \mathrm{NaOH})$.

Then, $20 \mathrm{~mL}$ of dye solution $\left(11.0 \mathrm{mg} \mathrm{L}^{-1}\right)$ was used to know the lowest adsorbent dosage that reaches the maximum TAR adsorption and the $\mathrm{pH}$ was fixed at 2.0. The adsorbent mass from 0.05 $\mathrm{g}$ to $0.25 \mathrm{~g}$, with $0.05 \mathrm{~g}$ increments per experiment, was used for $120 \mathrm{~min}$ at $25.0{ }^{\circ} \mathrm{C}$.

The highest dye concentration to better adsorption efficiency was determined in experiments with fixed values of $\mathrm{pH}(2.0)$ and adsorbent dosage $\left(7.5 \mathrm{~g} \mathrm{~L}^{-1}\right)$, varying the TAR concentration from 2.5 to $25.0 \mathrm{mg} \mathrm{L}^{-1}$, in increments of $2.5 \mathrm{mg} \mathrm{L}^{-1}$ per experiment, for $120 \mathrm{~min}$ at $25.0{ }^{\circ} \mathrm{C}$.

\subsection{Isotherms of adsorption}

The experiments of isotherm adsorption were carried out in three $\mathrm{pH}$ values 1.0, 2.0, and 3.0, obtained by standardized solutions of $\mathrm{HCl}$. It was evaluated eight dye concentrations of TAR from 2.5 to $25.0 \mathrm{mg} \mathrm{L}^{-1}$, in increments of $2.5 \mathrm{mg} \mathrm{L}^{-1}$ per experiment), dosage of $7.5 \mathrm{~g} \mathrm{~L}^{-1}$ of adsorbent (AC, CAW or PPW), at $25.0^{\circ} \mathrm{C}$ and $120 \mathrm{~min}$, in an incubator shaker. The percentage values of adsorption (\% Ads) were determinated as described in Eq. 1.

The mathematical models of Langmuir (Eq. 2-3), Freundlich (Eq. 4) and Temkin (Eq. 5), expressed in their linearized forms, were applied to data in order to define the best model for each residue [22, 24-26].

Eq. 2 shows Langmuir model, where $q_{\max }$ is the maximum adsorption capacity $\left(\mathrm{mg} \mathrm{g}^{-1}\right), C_{e}$ is equilibrium concentration the and $K_{L}$ is the Lagmuir affinity constant $\left(\mathrm{L} \mathrm{mg}^{-1}\right)$. In the Langmuir 
isotherm the separation fator $\left(\mathrm{R}_{\mathrm{L}}\right)$ can also be calculated (Eq. 3), as adimensionless constant, which can indicate the adsorption nature: irreversible $\left(\mathrm{R}_{\mathrm{L}}=0\right)$, linear $\left(\mathrm{R}_{\mathrm{L}}=1\right)$, favorabele $\left(0<\mathrm{R}_{\mathrm{L}}<1\right)$ and unfavorable $\left(\mathrm{R}_{\mathrm{L}}>1\right)$.

$$
\begin{gathered}
\frac{1}{q_{e}}=\frac{1}{q_{\max }}+\frac{1}{K_{L} q_{\max } C_{e}} \\
R_{L}=\frac{1}{1+K_{L} C_{0}}
\end{gathered}
$$

In the Freundlich model (Eq. 4), $K_{F}$ is the adsorption capacity constant the Freundlich (mg g ${ }^{-1}$ ) and $1 / n$ indicates the existence of affinity between the adsorbate and adsorvente (favorable adsorption: $1 / n<1)$.

$$
\log q_{e}=\log K_{F}+\frac{1}{n} \log C_{e}
$$

According to Temkin model (Eq. 5), expressed in the linearized forms, $\mathrm{K}_{\mathrm{T}}$ is the Temkin equilibrium constant and $\mathrm{b}$ is the constant related to the heat of sorption.

$$
q_{e}=B \ln K_{T}+B \ln C_{e}
$$

\subsection{Application for industrial effluent treatment}

Effluent adsorption studies were carried out to evaluate the potential application of PPW and CAW as biosorbents. The effluent from a batch of orange juice, containing TAR dye in the composition, was donated by an industry of the Northwest region of the state of Paraná, Brazil, located near $(\sim 80 \mathrm{~km})$ to the industries that donated PPW and CAW.

The adsorption tests on the industrial effluent were performed using $0.15 \mathrm{~g}$ of each biosorbent and $20 \mathrm{~mL}$ of effluent at $\mathrm{pH} 2.0$ in Erlenmeyer flasks of $250 \mathrm{~mL}$, at $120 \mathrm{rpm}$ and $25.0{ }^{\circ} \mathrm{C}$ in the shaker. The experiments were performed in triplicate. Since the natural $\mathrm{pH}$ of the effluent was 3.5 , it was necessary to acidify the samples with $0.10 \mathrm{~mol} \mathrm{~L}^{-1} \mathrm{HCl}$ solution, to reach the $\mathrm{pH} 2.0$, according to the previous tests carried out in this work. In this condition, a first adsorption cycle of 105 min was performed for PPW and CAW, considering the equilibrium time. Afterwards, the solid material was separated and a second adsorption cycle was carried out, with the addition of new biosorbents, for each effluent treated by the first cycle, under the same previous conditions.

The percentage of adsorption reduction (\% Ads) of the treated effluent in each cycle was determined by comparing the initial and final absorbance values at $428 \mathrm{~nm}$ as described by Eq. 1 .

After the cycles, the color parameters were determined in the effluent, based on the CIELAB color system [27, 28], using a CR-400 Chroma Meter colorimeter (Konica Minolta). The coordinate $\mathrm{b}^{*}$, with positive values, indicates the yellow color intensity. Luminosity $\left(\mathrm{L}^{*}\right)$ expresses the amount of light reflected by a color, that is, the brightness of a certain object, with values ranging between 0 (black) and 100 (white).

\section{RESULTS AND DISCUSSION}

\subsection{Characterization of biosorbents}

\subsubsection{Chemical Composition}

The composition of by-products used in this work (Table 1) showed that biosorbents had low moisture and ashes contents, which were slightly higher in PPW when compared with CAW. 


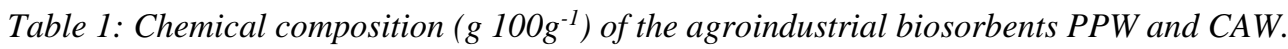

\begin{tabular}{ccc}
\hline Parameter & PPW & CAW \\
\hline Moisture & $9.31 \pm 0.20$ & $8.33 \pm 0.17$ \\
Ashes & $3.50 \pm 0.08$ & $1.80 \pm 0.05$ \\
Celullose & $51.20 \pm 0.80$ & $31.47 \pm 0.55$ \\
Hemicellulose & $17.03 \pm 0.79$ & $0.53 \pm 0.01$ \\
Lignin & $7.17 \pm 0.40$ & $0.40 \pm 0.03$ \\
Starch & ND & $29.40 \pm 0.85$ \\
Protein & $4.37 \pm 0.29$ & $2.37 \pm 0.01$
\end{tabular}

ND - not detectable.

Cellulose was the main component of the biosorbents and its content was higher in PPW than CAW. Lower values of cellulose were reported in other studies, ranging between 32.6 and $34.2 \mathrm{~g}$

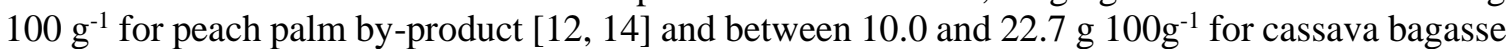
$[2,29]$. The other fibrous components - hemicellulose and lignin - were found in higher percentages in PPW when compared to CAW, and these values were lower than those presented in previous studies $[12,29]$. Starch is an important component of CAW, but the value found in this work was lower than those observed in other works $\left(40.5\right.$ to $77.0{\left.\mathrm{~g} 100 \mathrm{~g}^{-1}\right)}^{2}[3,11,29]$. There was no experimental measurement of PPW starch content due to its low content. The lower contents of hemicellulose, lignin and starch than those found by the studies cited above may be related to the solubilization of these compounds, in the washing step of biosorbents preparation, leading to a concentration of cellulose. The results obtained in this study indicated that the CAW had 55.9 \pm 0.9 g $100 \mathrm{~g}^{-1}$ of starch before washing, which shows the loss of carbohydrates during the process of material preparation. Furthermore, variation of chemical composition is common among lignocellulosic materials and it can be attributed to differences in species, plant age and cultivation conditions, such as soil, geographical location and climate [30]. In the case of cassava bagasse, such variation can also be attributed to differences in the process of starch extraction between industrial units [29].

PPW had higher protein content than CAW. The basic components present in agricultural residues such as cellulose, hemicellulose, lignin, proteins and starch can influence the adsorption process due to the presence of functional groups [31], such as hydroxyl, phenols and methoxy, which can physically adsorb dye molecules with hydrogen bonding and/or Van der Waals interactions [32].

\subsubsection{Infrared Spectroscopy}

The functional groups present on the surface of the PPW and CAW were identified by the ATRFTIR (Figure 3). The spectra show that biosorbents had similar behavior regarding peaks, and the results obtained can be attributed mainly to cellulose, as the main components of the wastes [33]. The broadband centered around $3325 \mathrm{~cm}^{-1}$ and $3332 \mathrm{~cm}^{-1}$ is attributed to $\mathrm{OH}$ link stretches [34,35], elongation of the hydroxyl group, alcohols, and phenols or carboxylic acid [36], belonging to the structure of cellulose, hemicellulose [37], lignin [12], and starch [34]. Moreover, the presence of moisture may have contributed to the intensity of the band in this region [33]. 


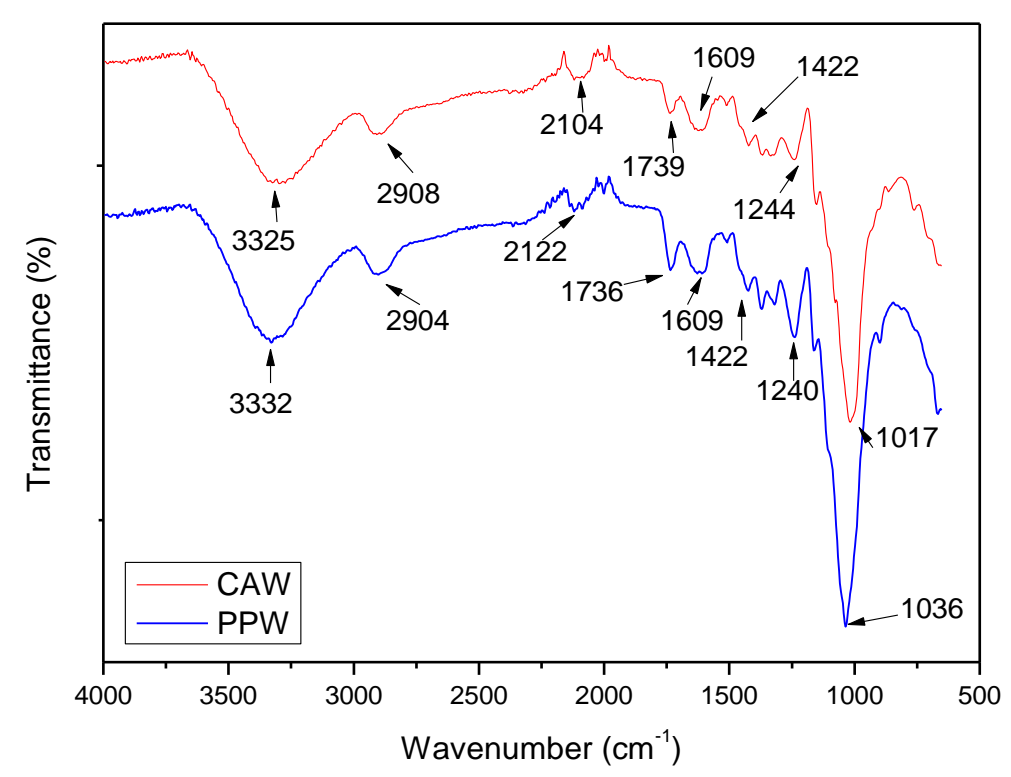

Figure 3: ATR-FTIR spectra for peach palm waste (PPW) and cassava waste (CAW).

The adsorption bands at $2904 \mathrm{~cm}^{-1}$ and $2908 \mathrm{~cm}^{-1}$ can be attributed to the $\mathrm{C}-\mathrm{H}$ stretch vibration of the methyl and methylene groups [38,39]. The vibrations seen at $1736 \mathrm{~cm}^{-1}$ and $1739 \mathrm{~cm}^{-1}$ are attributed to the $\mathrm{C}=\mathrm{O}$ extension, stretching in aldehydes, ketones groups, and esters [32, 40]. Vibrations in $1609 \mathrm{~cm}^{-1}$ can be attributed to the carbonyl group, present in lignin and protein [33]. The bands in the region of $1422 \mathrm{~cm}^{-1}$ indicate torsional vibrations of $\mathrm{O}-\mathrm{H}$ present in cellulose, hemicellulose and lignin structures [29]. Whereas peaks at $1244 \mathrm{~cm}^{-1}$ can be associated to the extended $\mathrm{C}-\mathrm{O}$ vibrations of alcohol, carboxylates and phenol [41]. Finally, it was observed an elongation of C-O, C-C, and C-C-O at the $1017 \mathrm{~cm}^{-1}$ and $1031 \mathrm{~cm}^{-1}$ peaks, which can be attributed to the asymmetric $\mathrm{C}-\mathrm{O}-\mathrm{C}$ elongation of cellulose, hemicellulose and lignin [42]. The CAW spectrum at $1017 \mathrm{~cm}^{-1}$ can also be attributed to the amylose $\mathrm{C}-\mathrm{O}$ and $\mathrm{C}-\mathrm{C}$ bonds to amylopectin, constituents of starch [43].

Considering the set of bands presented in the ATR-FTIR spectra, it is possible to observe the presence of functional groups common to cellulose, hemicellulose, lignin, starch, components identified in the biosorbents (Table 1). Thus, it seems that the biosorbents investigated in this study are composed of several functional groups, which can contribute to the adsorption process.

\subsubsection{Scanning Electron Microscopy}

The scanning electron microscopies of the biosorbents CAW (Figure 1S) and PPW (Figure 2S) show that the materials have an irregular, heterogeneous surface with the presence of fibers, which are more characteristic in PPW.

In the micrographs of Fig. 1S it is possible to notice the presence of starch granules in the CAW, which have rounded shapes as previously reported [41]. Furthermore, it was found that the morphology of PPW (Fig. 2S) and CAW biosorbents is fragmented, rough and porous. These available spaces contribute to the adsorption process, since they provide a high internal surface area [44].

\subsubsection{Zero point of charge $\left(\mathrm{pH}_{z p c}\right)$}

Figure 4 shows the results of $\mathrm{pH}_{\mathrm{zpc}}$ analyzes of the $\mathrm{PPW}$ and $\mathrm{CAW}$ biosorbents. The $\mathrm{pH}_{\mathrm{zpc}}$ values correspond to the point at which the final $\mathrm{pH}$ curve, as a function of the initial $\mathrm{pH}$, cuts the $\mathrm{x}$ axis [44]. 


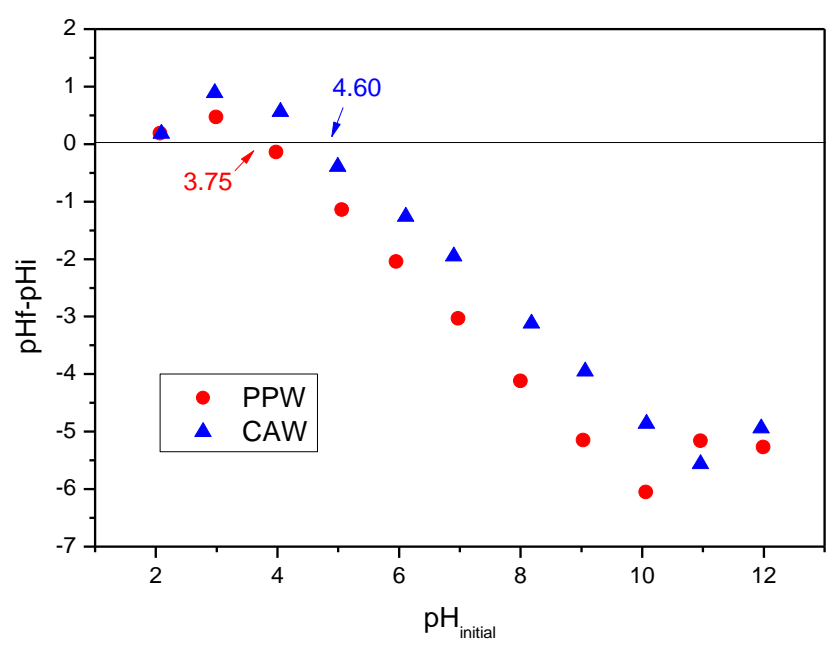

Figure 4: $p H_{z p c}$ of PPW and CAW biosorbents.

It was observed that the $\mathrm{pH}_{\mathrm{zpc}}$ of the PPW biosorbent was 3.75, whereas CAW was 4.60. These values indicate the $\mathrm{pH}$ necessary for the residues present zero electrically charged surfaces [44]. Therefore, the $\mathrm{pH}_{\mathrm{zpc}}$ values provide significant information for the analysis of electrostatic interactions between substrates and biosorbents [22]. This is because, when the $\mathrm{pH}$ of the solution is higher than $\mathrm{pH}_{\mathrm{zpc}}$, the surface of the material is negatively charged. On the other hand, at $\mathrm{pH}$ values lower than $\mathrm{pH}_{\mathrm{zpc}}$, there is a favor in anion adsorption, since the surface is positively charged [45]. Tartrazine is an anionic dye, that is, negatively charged. Therefore, its adsorption is favored at $\mathrm{pH}$ values below $\mathrm{pH}_{\mathrm{zpc}}[44]$.

\subsection{Adsorption studies}

\subsubsection{Time of adsorption evaluation}

The determination of the time necessary for adsorption process stabilizes is essential to ensure the dye uptake reaches a saturation point (equilibrium) [46]. Therefore, Figure 5 presents the results obtained in the analysis of the effect of contact time in the removal of TAR for the CAW, PPW, and $\mathrm{AC}$ adsorbents.

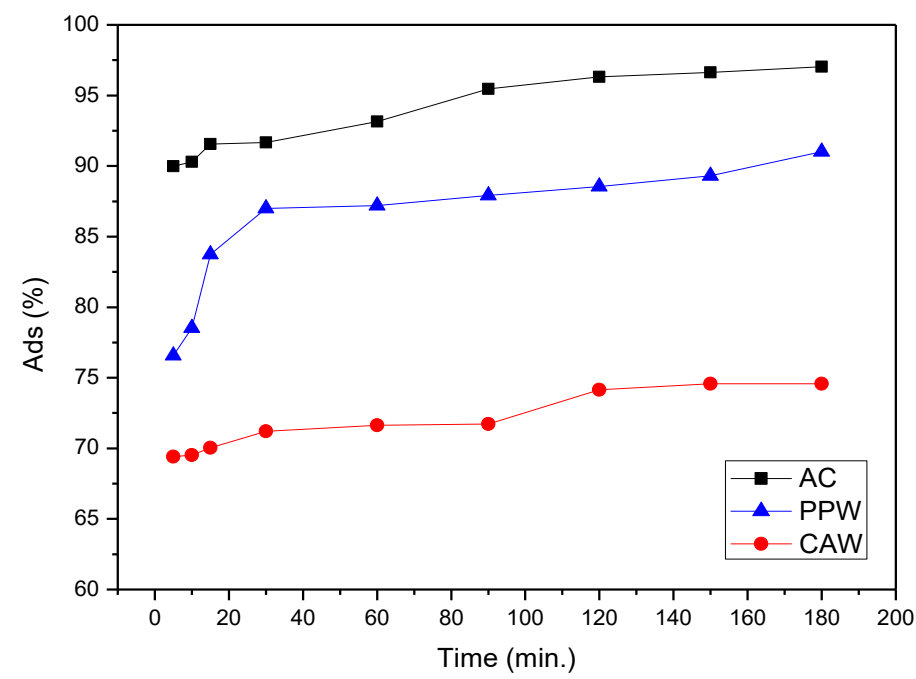

Figure 5: Effect of time removal of TAR dye for $P P W, C A W$ and $A C$ adsorbents. Experimental conditions: $p H=2.0,[T A R]=11.0 \mathrm{mg} \mathrm{L}^{-1}$, temperature $=25.0^{\circ} \mathrm{C}$, dosage $=7.5 \mathrm{~g} \mathrm{~L}^{-1}$, stirring at $120 \mathrm{rpm}$. 
Figure 5 shows that TAR adsorption was fast in the initial stages, and after five minutes the percentage of removal were $90.0 \% \pm 0.4,76.2 \% \pm 1.0$, and $69.6 \% \pm 0.4$ for AC, PPW, and CAW, respectively. This high adsorption, which was achieved in a short period of time, indicates a high affinity between dye molecules and the surfaces of the adsorbents. Studies carried out with TAR also demonstrated rapid stabilization in the initial stages of adsorption [45, 47, 48]. For the AC (used as a model), the removal percentage has a slightly increase with time until reaching equilibrium at $90 \mathrm{~min}$, with about $96.0 \% \pm 0.1$ adsorption. Notably, PPW presented a gradual increase in adsorption, reaching equilibrium in $30 \mathrm{~min}$, with about $87.0 \% \pm 0.9$. On the other hand, CAW presented less variation in the percentage of adsorption, reaching equilibrium at $120 \mathrm{~min}$, with approximately $74.0 \% \pm 0.8$ of adsorption. Considering the small variation in adsorption shown in Fig. 4, 120 min was standardized as the time sufficient to monitor the adsorption process under other experimental conditions (TAR concentration, $\mathrm{pH}$, dosage), since saturation and adsorption process had already been identified for all analyzed biosorbents.

\subsubsection{Effect of $\mathrm{pH}$}

The $\mathrm{pH}$ is a significant factor in the adsorption process, since it has a direct influence on adsorbent surface load, degree of ionization of the adsorbate functional groups, and adsorption mechanism [49]. The effect of $\mathrm{pH}$ on the TAR adsorption behavior is shown in Figure 6 .

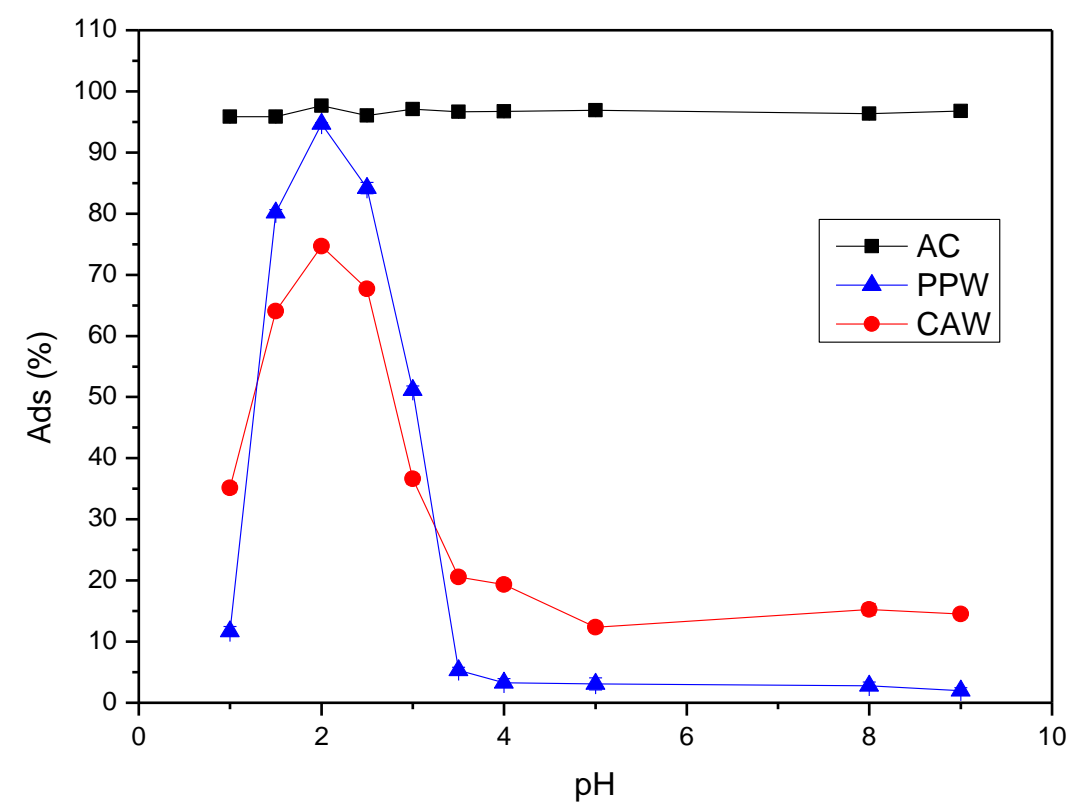

Figure 6: Effect of pH on the removal of TAR dye by PPW, CAW and AC adsorbents, in time $=120 \mathrm{~min}$, $[T A R]=11.0 \mathrm{mg} \mathrm{L}^{-1}$, temperature $=25.0^{\circ} \mathrm{C}$, dosage $=7.5 \mathrm{~g} \mathrm{~L}^{-1}$, stirring at $120 \mathrm{rpm}$.

Based on Fig. 6 it is possible to notice that the AC showed few variations in adsorption among all different $\mathrm{pHs}$ evaluated, with adsorption percentage remaining around 97.7\% \pm 0.6 . Even with the effect of fillers, activated carbon has a high number of active sites easing the adsorption in different $\mathrm{pH}$ values [44]. Fig. 6 shows that the maximum TAR adsorption was reached at $\mathrm{pH} 2.0$ for PPW and CAW, removing 94.7\% \pm 0.2 and $74.4 \% \pm 0.5$, respectively, which is consistent with other studies [44, 48, 50,51]. Furthermore, it is necessary to show that the removal efficiency of TAR for PPW was similar to that of AC, with a ratio above $90 \%$. Therefore, this residue has a great adsorptive potential, even without being subjected to carbon activation processes and chemical treatments. 
When in alcali medium, a significant reduction in the efficiency of adsorption with the solution occurred. At $\mathrm{pH} 9.0$ the percentage of removal was $14.5 \% \pm 0.5$ and $2.0 \% \pm 0.5$, for CAW and PPW, respectively. These values demonstrate that CAW still provides adsorption in alcali medium, but less efficiently. On the other hand, under the same conditions, the efficiency of the PPW is almost null. The materials $\mathrm{pH}_{\mathrm{zpc}}$ is manly associated with this behavior. There is a significantly high electrostatic attraction force between positive surfaces of the biosorbents and anionic dye, which affects the high removal of pollutants in an acidic medium. On the other hand, with the increase in $\mathrm{pH}$, the positively charged sites decrease and the adsorbent surface becomes negative, a fact that leads to lower percentages of adsorption as the $\mathrm{pH}$ values increase. With the results of CAW and PPW it is possible to observe that the best adsorption occurs in an acid medium and the best efficiency value is at $\mathrm{pH} 2.0$ for both biosorbents.

\subsubsection{Effect of dosage}

The effect of the biosorbent dosage on the adsorption process (Figure 7) showed that CAW and PPW had similar behaviors, i.e., higher biosorbents concentration promote higher adsorption efficiency. In the $2.5 \mathrm{~g} \mathrm{~L}^{-1}$ dosage, the adsorption was $35.8 \% \pm 0.1$ for CAW and $67.0 \% \pm 0.4$ for PPW, and when the concentration increased to $12.5 \mathrm{~g} \mathrm{~L}^{-1}$, the efficiency increased, reaching $83.3 \%$ \pm 0.1 and $93.2 \% \pm 0.2$, respectively. In the case of AC, used as a comparison standard, the efficiency ranged from $90.4 \% \pm 0.3$ to $99.9 \% \pm 0.1$ in the same interval $\left(2.5 \mathrm{~g} \mathrm{~L}^{-1}\right.$ to $\left.12.5 \mathrm{~g} \mathrm{~L}^{-1}\right)$.

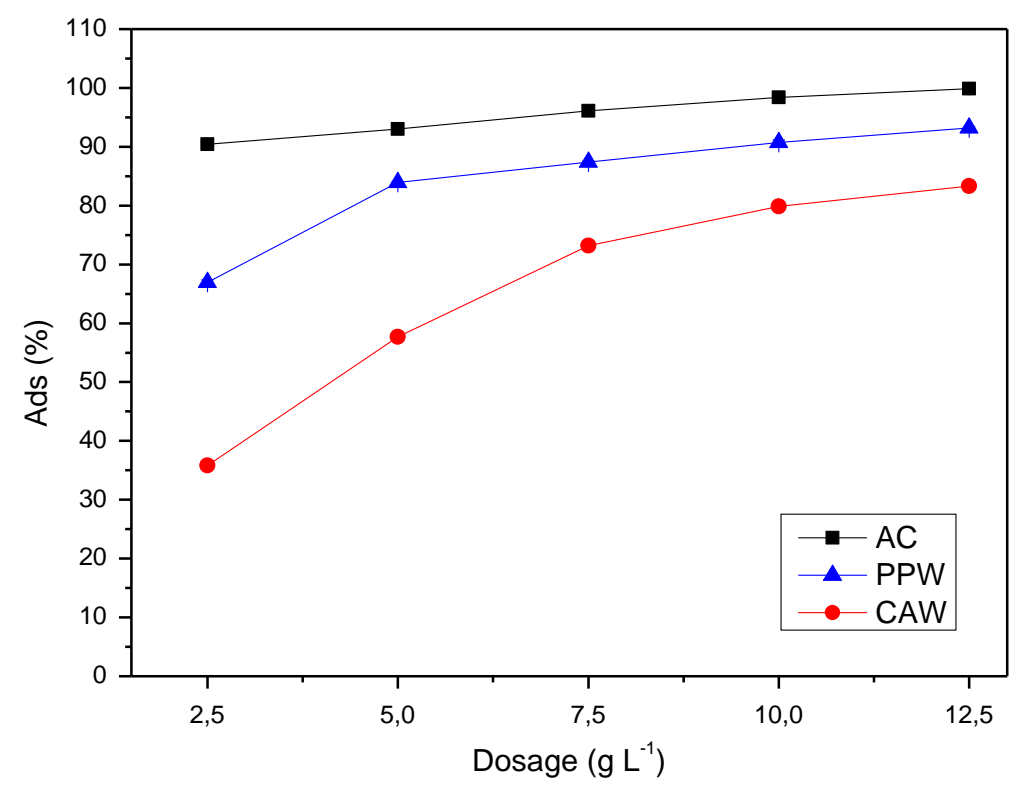

Figure 7: Effect of dosage on the removal of TAR dye for the adsorbents $P P W, C A W$ and AC at $p H=2.0$, Time $=120 \mathrm{~min},[T A R]=11.0 \mathrm{mg} \mathrm{L^{-1 }}$, temperature $=25.0{ }^{\circ} \mathrm{C}$, stirring at $120 \mathrm{rpm}$ and volume $=20 \mathrm{~mL}$.

This efficiency raise associated with the increase in biosorbent dosage can be explained by the high availability of adsorbent for a fixed dye concentration $\left(11.0 \mathrm{mg} \mathrm{L}^{-1}\right)$. Thus, the higher the biosorbent mass the higher is the contact area, consequently a high number of active sites are available to be occupied by adsorbed TAR molecules. For subsequent experiments, the dosage of $7.5 \mathrm{~g} \mathrm{~L}^{-1}$ was established as the most appropriate, since this value is close enough to the limit value shown in Fig. 7 and it provides material savings. 


\subsubsection{Effect of dye concentration}

The study of the effect of dye concentration on the occurrence of adsorption process (Figure 8) is important to assess the ability of a given mass of adsorbent to remove different concentrations of dye.

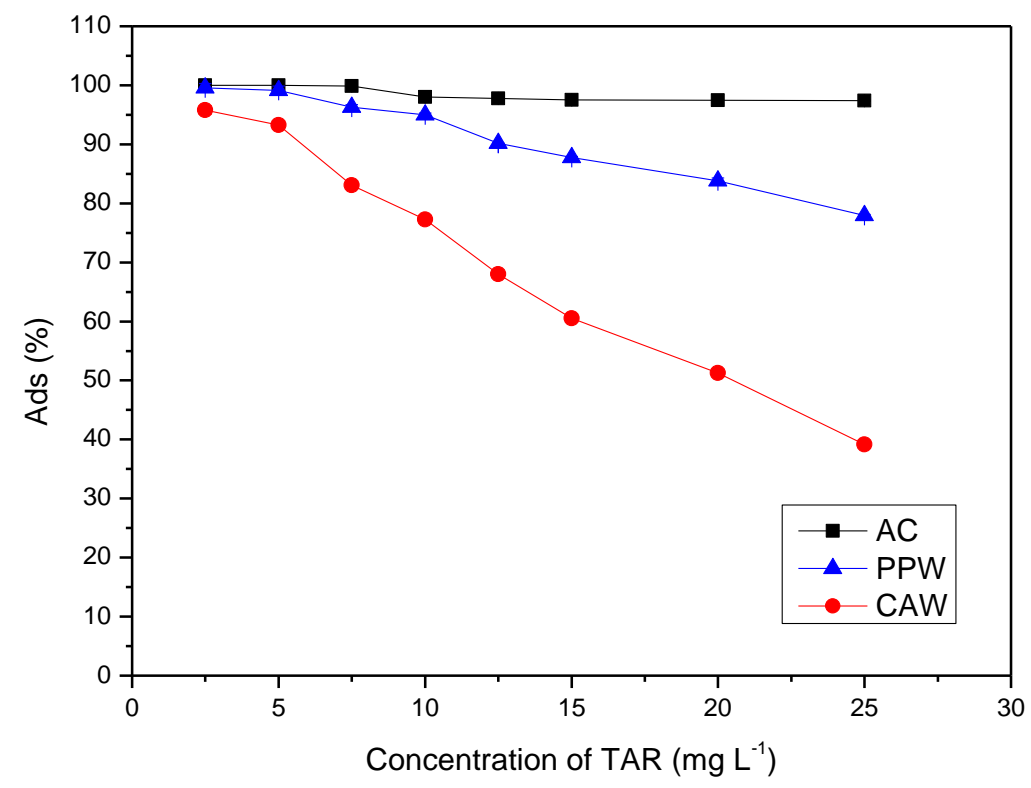

Figure 8: Effect of Concentration on the removal of TAR dye for PPW, CAW and AC adsorbents at pH= 2.0, Time $=120 \mathrm{~min}$, temperature $=25.0^{\circ} \mathrm{C}$, stirring at $120 \mathrm{rpm}$.

The increase in TAR concentration from $2.5 \mathrm{mg} \mathrm{L}^{-1}$ to $25 \mathrm{mg} \mathrm{L}^{-1}$, reduced the adsorption from $95.8 \% \pm 0.7$ to $39.1 \% \pm 0.5$ for CAW and from $99.6 \% \pm 0.7$ to $77.9 \% \pm 0.2$ for PPW. Once again, AC showed adsorption percentages close to $100 \%$. Thus, it is possible to observe that with the increase in dye concentration, the percentage of removal of the TAR dye decreased, both for CAW and PPW. This behavior can be attributed to the fact that at low concentration values there is a reduced number of dye molecules and, therefore, there is less competition for active sites for adsorption.

The highest values of adsorption efficiency were observed in low dye concentrations, such as $2.5 \mathrm{mg} \mathrm{L}^{-1}$ and $10 \mathrm{mg} \mathrm{L}^{-1}$, for both CAW and PPW. However, for the subsequent tests it was defined at $11.0 \mathrm{mg} \mathrm{L}^{-1}$ since this is common in industrial effluents from artificial orange juices in which the TAR dye is used. At this concentration, there was an efficiency of approximately $77.3 \% \pm 0.1$ and $95.0 \% \pm 0.3$ when using CAW and PPW as a biosorbent, respectively.

\subsection{Adsorption isotherms}

The adsorption isotherms are important to understand the mechanism of adsorption process, as well as to evaluate the adsorption equilibrium constants [26]. The application of the adsorption models isotherms of Langmuir, Freundlich, and Temkim for TAR by AC, CAW and PPW in pH 1.0, 2.0, and 3.0 (not shown) are expressed by statistical parameters $\mathrm{R}^{2}$ (determination coefficient) and RSS (residual sum of squares) from linear adjustment of the models (Table 2). 
Table 2: Constants of adsorption of Langmuir, Freundlich and Temkim isotherms for the removal of TAR with $A C, C A W$ and $P P W$ in $\mathrm{pH}$ 1.0, 2.0 and 3.0, at $25.0^{\circ} \mathrm{C}$, dosage $7.5 \mathrm{~g} \mathrm{~L}^{-1}$.

\begin{tabular}{|c|c|c|c|c|c|c|c|c|c|}
\hline \multirow{2}{*}{$\begin{array}{l}\text { Adsorbents } \\
\text { pH }\end{array}$} & \multicolumn{3}{|c|}{$\mathbf{A C}$} & \multicolumn{3}{|c|}{ CAW } & \multicolumn{3}{|c|}{ PPW } \\
\hline & 1.0 & 2.0 & 3.0 & 1.0 & 2.0 & 3.0 & 1.0 & 2.0 & 3.0 \\
\hline \multicolumn{10}{|l|}{ Langmuir } \\
\hline $\mathrm{q}_{\text {máx }}\left(\mathrm{mg} \mathrm{g}^{-1}\right)$ & 6.329 & 7.299 & 8.621 & 1.464 & 1.414 & 1.558 & 2.347 & 2.320 & 2.519 \\
\hline $\mathrm{K}_{\mathrm{L}}\left(\mathrm{L} \mathrm{mg}^{-1}\right)$ & 1.295 & 1.070 & 0.817 & 1.062 & 1.124 & 0.933 & 2.328 & 2.435 & 2.079 \\
\hline $\mathrm{R}_{\mathrm{L}}$ & 0.236 & 0.272 & 0.329 & 0.274 & 0.262 & 0.300 & 0.147 & 0.141 & 0.161 \\
\hline $\mathrm{R}^{2}$ & 0.953 & 0.980 & 0.983 & 0.977 & 0.978 & 0.948 & 0.926 & 0.921 & 0.923 \\
\hline RSS & 0.005 & 0.002 & 0.002 & 0.003 & 0.003 & 0.008 & 0.017 & 0.018 & 0.019 \\
\hline \multicolumn{10}{|l|}{ Freundlich } \\
\hline $\mathrm{K}_{\mathrm{F}}$ & 1.866 & 1.893 & 1.900 & 0.930 & 0.931 & 0.930 & 1.185 & 1.186 & 1.208 \\
\hline $\mathrm{N}$ & 1.359 & 1.319 & 1.252 & 4.878 & 5.319 & 4.348 & 3.086 & 3.086 & 2.793 \\
\hline $\mathrm{R}^{2}$ & 0.978 & 0.991 & 0.993 & 0.933 & 0.877 & 0.882 & 0.978 & 0.982 & 0.969 \\
\hline RSS & 0.002 & $6.6 \times 10^{-4}$ & $5.3 \times 10^{-4}$ & 0.002 & 0.003 & 0.004 & 0.002 & 0.002 & 0.003 \\
\hline \multicolumn{10}{|l|}{ Temkim } \\
\hline $\mathrm{K}_{\mathrm{T}}\left(\mathrm{L} \mathrm{mg}^{-1}\right)$ & 10.732 & 10.416 & 9.293 & 37.116 & 59.343 & 22.333 & 18.774 & 18.984 & 15.065 \\
\hline $\begin{array}{l}\mathrm{B}=\mathrm{RT} / \mathrm{b} \\
(\mathrm{J} / \mathrm{mol})\end{array}$ & 1.546 & 1.599 & 1.688 & 0.228 & 0.204 & 0.264 & 0.533 & 0.532 & 0.605 \\
\hline $\mathrm{R}^{2}$ & 0.921 & 0.944 & 0.948 & 0.964 & 0.895 & 0.882 & 0.950 & 0.949 & 0.939 \\
\hline RSS & 0.143 & 0.102 & 0.095 & 0.006 & 0.016 & 0.029 & 0.073 & 0.076 & 0.104 \\
\hline
\end{tabular}

Table 2 shows that the experimental data of AC and PPW showed a better fit to the Freundlich model, since they obtained the highest coefficients of determination and the lowest error values. Freundlich's isotherm describes the adsorption on heterogeneous surfaces, with interaction between the adsorbed molecules and the formation of multilayers [17]. Therefore, the best fit to this model suggests that the adsorption of TAR by AC and PPW was not homogeneous, enabling the formation of several layers of dye on their surfaces [48]. On the other hand, CAW presented the best adjustments to Langmuir isotherm $\left(\mathrm{R}^{2}=0.948\right.$ to 0.978$)$, which indicates the occurrence of monolayer adsorption [52]. In this model, the adsorbent surface has a fixed number of energetically equivalent locations and there are no interactions between the adsorbed molecules [53]. Based on these models, it was possible to determine the constant of adsorption equilibrium for each bioadsorbent.

The parameters provided by the Langmuir model (Table 2) refer to the adsorption equilibrium constant $\left(\mathrm{K}_{\mathrm{L}}\right)$, which relates the affinity between the surface of adsorbent and the dye adsorbed and the maximum adsorption capacity ( $\mathrm{q}_{\text {máx }}$ ) [44]. It was found, by analyzing the $\mathrm{q}_{\text {max }}$ values, that $\mathrm{AC}$ (standard adsorbent) presents a higher adsorption capacity (6.329 to $\left.8.621 \mathrm{mg} \mathrm{g}^{-1}\right)$ than PPW (2.320 to $2.519 \mathrm{mg} \mathrm{g}^{-1}$ ) and CAW (1.414 to $1.558 \mathrm{mg} \mathrm{g}^{-1}$ ). When comparing these values with the maximum TAR adsorption capacities, reported by different residues, similar results were observed (Table 3). Although there are similar results to the found in the present study, there is a wide variation in the literature, since the results depend on experimental conditions and, mainly, on the interval used for the equilibrium concentration. 
Table 3: Comparison of the variables of Langmuir and Freundlich isotherms for the adsorption of TAR from literature.

\begin{tabular}{|c|c|c|c|c|c|c|c|c|}
\hline \multirow[t]{2}{*}{ Adsorbents } & \multirow[t]{2}{*}{ Operation Condition } & \multicolumn{4}{|c|}{ Langmuir } & \multicolumn{2}{|c|}{ Freundlich } & \multirow[t]{2}{*}{ Ref. } \\
\hline & & $\begin{array}{c}\text { qmáx } \\
\left(\mathrm{mg} \mathrm{g}^{-1}\right)\end{array}$ & $\begin{array}{c}\mathrm{K}_{\mathrm{L}} \\
\left(\mathrm{L} \mathrm{mg}^{-1}\right)\end{array}$ & $\mathrm{R}_{\mathrm{L}}$ & $\mathrm{R}^{2}$ & $\begin{array}{c}\mathrm{K}_{\mathrm{F}} \\
\left(\mathrm{mg} \mathrm{g}^{-1}\right)\end{array}$ & $\mathrm{R}^{2}$ & \\
\hline Sawdust & $\begin{array}{l}\text { Dosage: } 5 \mathrm{~g} \mathrm{~L}^{-1}, \mathrm{C}_{0}: 1 \text { to } \\
15 \mathrm{mg} \mathrm{L}-1 \text {, } \mathrm{pH}: 3.0, \mathrm{~T} \text { : } \\
25^{\circ} \mathrm{C} \text {, time: } 70 \mathrm{~min}\end{array}$ & 3.39 & 0.003 & 0.067 & 0.974 & 0.79 & 0.974 & [47] \\
\hline $\begin{array}{l}\text { Nanoparticles } \\
\text { (NPsFeOA) } \\
\text { using pumpkin } \\
\text { leaves } \\
\text { (Cucurbita } \\
\text { moschata) }\end{array}$ & $\begin{array}{l}10 \mathrm{~mL} \text { of solution, } \mathrm{C}_{0}: 25 \\
\text { to } 120 \mathrm{mgL}^{-1}, \mathrm{~m}: 10 \mathrm{mg} \text {, } \\
\text { pH: } 7, \mathrm{~T}: 25^{\circ} \mathrm{C} \text {, time: } \\
1200 \mathrm{~min}\end{array}$ & 75.44 & 0.98 & - & 0.97 & 51.87 & 0.93 & [19] \\
\hline $\begin{array}{l}\text { Activated } \\
\text { carbon of } \\
\text { babassu } \\
\text { coconut }\end{array}$ & $\begin{array}{l}\text { Dosage: } 0.2 \mathrm{~g}, \mathrm{~L}^{-1}, \mathrm{C}_{0}: 15 \\
\mathrm{mg} \mathrm{L}{ }^{-1}, \mathrm{pH}: 3.0, \mathrm{~T}: 25 \\
{ }^{\circ} \mathrm{C} \text {, time: } 720 \mathrm{~min}\end{array}$ & 31.10 & 0.056 & 0.201 & 0.976 & 2.84 & 0.979 & [44] \\
\hline Moringa seeds & $\begin{array}{l}\text { Dosage: } 4.0 \mathrm{~g} \mathrm{~L}^{-1}, \mathrm{C}_{0}: 15 \\
\mathrm{mg} \mathrm{L} \mathrm{L}^{-1}, \mathrm{pH}: 3.0, \mathrm{~T}: 25 \\
{ }^{\circ} \mathrm{C} \text {, time: } 240 \mathrm{~min}\end{array}$ & 72.08 & 0.051 & 0.218 & 0.943 & 3.05 & 0.936 & [44] \\
\hline $\begin{array}{l}\text { Activated bone } \\
\text { carbon }\end{array}$ & $\begin{array}{l}\mathrm{C}_{0}: 15 \mathrm{mgL}^{-1}, \mathrm{~m}: 0.2 \mathrm{~g}, \mathrm{pH}: \\
2, \mathrm{~T}: 25^{\circ} \mathrm{C} \text {, time: } 600 \\
\text { min }\end{array}$ & 17.19 & 0.063 & 0.184 & 0.969 & 1.64 & 0.952 & [44] \\
\hline $\begin{array}{l}\text { Commercially- } \\
\text { activated } \\
\text { carbon }\end{array}$ & $\begin{array}{l}\text { Dosage: } 0.01{\mathrm{~g} 10 \mathrm{~mL}^{-1} \text {, }} \mathrm{C}_{0}: 30-200 \mathrm{mg} \mathrm{L}^{-1}, \mathrm{pH}: \\
\text { 5.0; T: } 25^{\circ} \mathrm{C} \text {. }\end{array}$ & 67.79 & 1.373 & 0.023 & 0.998 & 38.11 & 0.691 & {$[54]$} \\
\hline
\end{tabular}

Regarding the $\mathrm{K}_{\mathrm{L}}$ values, it was observed that PPW presented the highest values (2.079 to 2.328 $\left.\mathrm{L} \mathrm{mg}^{-1}\right)$, surpassing even those presented by the standard adsorbent $(0.817$ to 1.295$)$ and the values reported in different studies (Table 3 ).

Another essential feature of Langmuir adsorption is the separation factor $\left(\mathrm{R}_{\mathrm{L}}\right)$, estimated based on equilibrium constant $\left(\mathrm{K}_{\mathrm{L}}\right)$ and initial dye concentration $\left(\mathrm{C}_{0}\right)$ [48]. $\mathrm{R}_{\mathrm{L}}$ values (Table 2) showed that AC, CAW and PPW favor the adsorption of TAR in the three $\mathrm{pH}$ conditions $\left(0<\mathrm{R}_{\mathrm{L}}<1\right)[36$, $44,50]$.

The results presented with the adjusted Freundlich model are expressed by the constants $\mathrm{K}_{\mathrm{F}}(\mathrm{mg}$ $\mathrm{g}^{-1}$ ) and $\mathrm{n}$, respectively $[17,48]$. The $\mathrm{K}_{\mathrm{F}}$ values (Table 2) ranged between 0.930 and 1.900 and they presented the following order AC> PPW> CAW. Previous studies with the TAR dye obtained similar results using sawdust and bone activated carbon (Table 3 ). The $n$ values presented in Table 2 were identified for the three adsorbents studied and they represent favorable conditions for adsorption since they are higher than the unity $[36,38]$. These results demonstrate that CAW and PPW biosorbents present favorable conditions for TAR adsorption, without applying high cost treatments in their production.

For AC and PPW, the best adjusted model was Freundlich's, which provides an empirical model for the process. $\mathrm{K}_{\mathrm{F}}$ values for $\mathrm{AC}$ were higher than PPW, indicating that the adsorption process is more favorable in AC than PPW, as expected, since AC is an adsorbent standard. In both cases, $\mathrm{K}_{\mathrm{F}}$ values were very similar to each other in relation to $\mathrm{pH}$, indicating highly favorable processes in the studied $\mathrm{pH}$ values. For CAW, the best model was Langmuir's, which infers a monolayer model in which the active sites of the bioadsorbents have identical energies. In this case, the $\mathrm{K}_{\mathrm{L}}$ values were lower than the $\mathrm{K}_{\mathrm{F}}$ values for the AC and PPW, which is consistent with the fact that the CAW presented the lowest $\%$ Ads values in the experiments. 


\subsection{Potential application for industrial effluent treatment}

The chemical composition of the juice effluent is quite complex and it involves a set of residues originated in the processes of manufacturing the juice, as well as substances used in the cleaning process. The previous analysis of the effluent showed an approximate $\mathrm{pH}$ of 3.5 and turbidity of $115 \mathrm{uT}$. According to industry data, the TAR is the main constituent of the effluent, with concentration of $11 \mathrm{mg} \mathrm{L}^{-1}$.

In this case, the investigation of the TAR adsorption present in an industrial effluent is essential, since the results showed the efficiency of PPW and CAW in adsorbing the pure dye. According to Table 4, the luminosity $\left(\mathrm{L}^{*}\right)$ of the effluent at $\mathrm{pH} 2.0$ was slightly higher than the value observed in the $\mathrm{pH} 3.5$, which is probably due to the protonation of the chromophoric groups of the dyes present in the effluent. Otherwise, the intensity of the yellow color $\left(b^{*}\right)$ was similar between the $\mathrm{pH}$ values evaluated.

Table 4: Percentage of adsorption reduction (\% Ads) and luminosity $\left(L^{*}\right)$ and yellow color intensity $\left(b^{*}\right)$ values for the initial effluent and after two adsorption cycles with the biosorbents PPW and CAW at pH 2.0 after $105 \mathrm{~min}(\mathrm{CAW})$ and $180 \mathrm{~min}(P P W)$, at $25.0^{\circ} \mathrm{C}$.

\begin{tabular}{lcccc}
\hline System & Treatment & \% Ads & L* & b* \\
\hline Effluent & pH 2.0 & NA & $65.4 \pm 1.2$ & $14.3 \pm 0.4$ \\
& pH in natura & NA & $61.7 \pm 1.0$ & $15.5 \pm 0.3$ \\
PPW & $1^{\text {st }}$ cycle & $55.8 \pm 3.5$ & $87.3 \pm 1.4$ & $1.9 \pm 0.1$ \\
(pH 2.0) & $2^{\text {nd }}$ cycle & $81.3 \pm 4.0$ & $91.1 \pm 0.4$ & $1.0 \pm 0.1$ \\
CAW & $1^{\text {st }}$ cycle & $49.5 \pm 0.2$ & $82.6 \pm 0.2$ & $2.2 \pm 0.1$ \\
(pH 2.0) & $2^{\text {nd }}$ cycle & $72.1 \pm 1.7$ & $87.8 \pm 0.6$ & $1.1 \pm 0.1$ \\
\hline
\end{tabular}

* NA - not applicable; PPW: peach palm waste; CAW: cassava bagasse

In the first cycle the adsorption efficiency was similar for PPW and CAW ( $53 \%$ of Ads reduction), and after the application of the second cycle, there was an increase in the adsorption percentage for both biosorbents, reaching $81.3 \%$ for PPW and $72.1 \%$ for CAW (Table 3). The luminosity increases after both treatment cycles, which was higher for PPW (91.1) than CAW (87.8), representing an increase of $39.2 \%$ and $34.2 \%$ in relation to the initial luminosity of the effluent, respectively, at $\mathrm{pH} 2.0$. The reduction of $\mathrm{b}^{*}$ values was similar for both biosorbents, and, after the second cycle, the values were $93.0 \%$ and $92.3 \%$ lower than the initial $b^{*}$ values, for the effluent at $\mathrm{pH}$ 2.0, for PPW and CAW, respectively.

The removal of these dyes by the industry generally is carried out by coagulation and flocculation processes, which require the addition of chemicals agents to alter the physical state of the dissolved / suspended solids and thus enable their removal by sedimentation $[55,56]$. The main coagulants and flocculants used include metallic salts, such as polyaluminium chloride, and synthetic polymers, such as polyacrylamide [57]. However, the use of these substances can negatively affect the environment and the consumer health, due to the increase in the sludge generation and/or metals concentration in the water [57].

Considering that the wastes used in this study have been neither subjected to carbon activation processes nor chemical treatments make them cheaper, in comparison with conventional adsorbents, and less aggressive to the environment when discarded incorrectly. Furthermore, the results indicate that both PPW and CAW biosorbents can be applied for treating industrial orange juice effluents. In addition to the TAR dye, the industrial effluent contains several compounds, that can influence the adsorption capacity, since the ions present in these compounds can bind to the surface of the adsorbent and occupy active sites or cause an ionic repulsion when binding to the adsorbate. Therefore, the application of a single cycle is often not sufficient for removing all pollutant, requiring two or more cycles. Another option to increase the process efficiency, under real conditions, involves the use of fixed bed adsorption columns [58-60]. This model is already used in the treatment of industrial effluents with dyes, however, with activated carbon [61]. This theme will be addressed further in more detailed studies. 


\section{CONCLUSION}

The biosorbents are composed of fibrous components, being cellulose the most abundant one

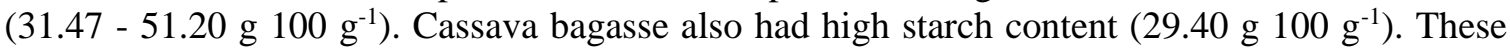
components were correlated with ATR-FTIR spectra. The micrographies showed that PPW and CAW biosorbents have irregular, heterogeneous and porous surface, which are considered positive characteristics for the adsorption process. Values of $\mathrm{pH}_{\mathrm{zpc}}$ were 3.75 for PPW and 4.60 for CAW. The adsorption tests demonstrated that PPW had higher percentages of removal of pure dye (94.7\%) than CAW (74.4\%) under the following experimental conditions: $\mathrm{T}=25.0^{\circ} \mathrm{C}, \mathrm{pH} 2.0, \mathrm{C}_{0}=11.0 \mathrm{mg}$ $\mathrm{L}^{-1}$, dosage $=7.5 \mathrm{mg} \mathrm{L}^{-1}$, time $=120 \mathrm{~min}$. Furthermore, PPW presented values of dye removal similar to that of commercial AC, used as a standard model. For CAW, Langmuir model provides the best fit to the experimental data, suggesting monolayer adsorption on homogeneous surface. On the other hand, the PPW results of isotherms were better described by Freundlich model, indicating the adsorption in multiple layers on a heterogeneous surface. For the treatment of industrial orange juice effluent, after two cycles, it was observed adsorption efficiency of $81.3 \%$ for PPW and $72.1 \%$ for CAW, as also, changes in the color parameters of the effluent, i.e., increase in luminosity $(39.2 \%$ $-34.2 \%)$ and decrease in yellow intensity $(93.0 \%-92.3 \%)$. Therefore, this study presented an alternative to minimize the inadequate disposal of wastes (CAW and PPW) in the environment, with economic benefits to agro-industrial chains, considering that the use of them as biosorbent had potential to be applied in the treatment of industrial effluents.

\section{ACKNOWLENGMENTS}

The authors would like to thank to National Council for Scientific and Technological Development - CNPq [grant number 2492/2019 - SGP-UEM]; and the Coordination for the Improvement of Higher Education Personnel - CAPES [grant number 40004015074P6] for the scholarships granted. To the Complex of Support Centers for Research (COMCAP), of the State University of Maringá for the analysis of scanning electron microscopy and to the Federal Institute of Paraná, Campus Umuarama for the ATR-FTIR analysis.

\section{REFERENCES}

1. FAO F. and Food Agriculture Organization of the United Nations. The future of food and agriculture: Trends and challenges. FAO [Internet]; 2017 [cited 2020 mar 3]. Available from: http://www.fao.org/3/i6583e/i6583e.pdf

2. Edhirej A, Sapuan SM, Jawaid M, Zahari NI. Cassava/sugar palm fiber reinforced cassava starch hybrid composites: Physical, thermal and structural properties. Int J of Biol Macromol. 2017 Mar;101:75-83, doi:10.1016/j.ijbiomac.2017.03.045.

3. Pandey A, Soccol CR, Nigam P, Soccol VT, Vandenberghe LPS, Mohan R. Biotechnological potential of agro-industrial residues. II: cassava bagasse. Bioresour Technol. 2000 Aug;74(1):81-87, doi: 10.1016/S0960-8524(99)00143-1

4. A Eletta OA, Ighalo JO. A Review of fish scales as a source of biosorbent for the removal of pollutants from industrial effluents. USEP: J Res Inform C Eng. 2019 Jan;16(1):2479-2510, doi: 10.13140/RG.2.2.20511.61604

5. Fabre E, Lopes CB, Vale C, Pereira E, Silva CM. Valuation of banana peels as an effective biosorbent for mercury removal under low environmental concentrations. Sci of the Total Environ. 2020 Mar;709:135883, doi: 10.1016/j.scitotenv.2019.135883

6. Meseldzija S, Petrovic J, Onjia A, Volkov-Husovic T, Nesic A, Vukelic N. Utilization of agro-industrial waste for removal of copper ions from aqueous solutions and mining-wastewater. J Ind Eng Chem. 2019 Jul;75:246-252, doi: 10.1016/j.jiec.2019.03.031

7. Ponce J, Andrade JGS, Santos LN, Bulla K, Barros BCB, Favaro SL, Hioka N, Caetano W, Batistela VR. Alkali pretreated surgacane bagasse, rice husk and corn husk wastes as lignocellulosic biosorbents for dyes. Carbohyd. Polymer Techn. Appl. 2021 Dec;2:100061, doi: 10.1016/j.carpta.2021.100061

8. Volbrecht CP, Batistela VR, França IAC, Bolanho BC, Fávaro SL, Garcia JC, Keller M. Polyurethane foams synthesis with addition of banana peel and application as adsorbent of tartrazine dye. Rev Quím 
Ind. 2020 jan-mar;(766):47-55. Available from: https://www.abq.org.br/rqi/2014/766/RQI-766pagina47-Artigo-Tecnico.

9. Hsu TC. Experimental assessment of adsorption of $\mathrm{Cu} 2+$ and $\mathrm{Ni} 2+$ from aqueous solution by oyster shell powder. J Hazardous Mater. 2009 Nov;171(1-3):995-1000, doi: 10.1016/j.jhazmat.2009.06.105

10. FAOSTAT. Statistical, A.O. of the U.N. FAOSTAT [Internet]. [ cited 2020 mar 3]. Available from: http://www.fao.org/faostat/en/\#data/QC

11. Souza CB, Jonathan M, Saad SMI, Schols HA, Venema K. Characterization and in vitro digestibility of by-products from Brazilian food industry: Cassava bagasse, orange bagasse and passion fruit peel. Bioactive Carbohyd Dietary Fibre. 2018 Oct;16:90-99, doi: 10.1016/j.bcdf.2018.08.001

12. Franco TS, Potulski DC, Viana LC, Forville E, Andrade AS, Muniz GIB. Nanocellulose obtained from residues of peach palm extraction (Bactris gasipaes). Carbohyd Polym, 2019 Aug;218:8-19, doi: 10.1016/j.carbpol.2019.04.035

13. Steinmacher, DA, Guerra MP, Saare-Surminski K, Lieberei R. A temporary immersion system improves in vitro regeneration of peach palm through secondary somatic embryogenesis. Annals Botany. 2011 Dec;108(8):1463-1475, doi: 10.1093/aob/mcr033

14. Bolanho BC, Danesi EDG, Beléia AP. Peach palm (Bactris gasipaes Kunth) characterization and the potential of by-products flour processing. Food Sci Technol Res. 2013 Jan;19(6):1061-1069, doi: $10.3136 /$ fstr. 19.1061

15. Katheresan V, Kansedo J, Lau SY. Efficiency of various recent wastewater dye removal methods: A review. J Environ Chem Eng. 2018 Aug;6(4):4676-4697, doi: 10.1016/j.jece.2018.06.060

16. Angelova R, Baldikova E, Pospiskova K, Maderova Z. Magnetically modi fi ed Sargassum horneri biomass as an adsorbent for organic dye removal. J Clean Prod. 2016 Nov;137:189-194, doi:10.1016/j.jclepro.2016.07.068

17. Goscianska J, Marciniak M, Pietrzak R. Ordered mesoporous carbons modified with cerium as effective adsorbents for azo dyes removal. Separation Purification Technol. 2015 Nov;154(5):236-245, doi: 10.1016/j.seppur.2015.09.042

18. Feketea G, Tsabouri S. Common food colorants and allergic reactions in children: Myth or reality? Food Chem. 2017 Sep;230:578-588, doi: 10.1016/j.foodchem.2017.03.043

19. Barizão ACL, Silva MF, Andrade M, Brito FC, Gomes RG, Bergamasco R. Green synthesis of iron oxide nanoparticles for tartrazine and bordeaux red dye removal. J Environ Chem Eng. 2020 Feb;8(1):103618, doi:10.1016/j.jece.2019.103618

20. Asociation of Official analytical Chemists. Official Methods of Analysis of AOAC International. 18 ed. Washington (DC): AOAC; 2005.

21. Van Soest PJ, Wine RH. Use of detergents in the analysis of fibrous feeds. IV. Determination of plant cell-wall constituents. J of the AOAC Int. $1967 \mathrm{Feb} ; 50(1): 50-55$, doi: 10.1093/jaoac/50.1.50

22. Oliveira AVB, Rizzato TM, Barros BCB, Favaro SL, Caetano W, Hioka N, Batistela VR. Physicochemical modifications of sugarcane and cassava agro-industrial wastes for applications as biosorbents. Bioresour Technol Reports. 2019 Sep;7:100294, doi: 10.1016/j.biteb.2019.100294

23. Kosmulski M. Surface Charging and Points of Zero Charge. Boca Raton (FL): CRC Press; 2009.

24. Febrianto J, Kosasih AN, Sunarso J, Ju Y-H, Indraswati N, Ismadji S. Equilibrium and kinetic studies in adsorption of heavy metals using biosorbent: A summary of recent studies. J Hazardous Mater. 2009 Mar;162(2-3):616-645, doi: 10.1016/j.jhazmat.2008.06.042

25. Kegl T, Košak A, Lobnik A, Novak Z, Kralj AK, Ban I. Adsorption of rare earth metals from wastewater by nanomaterials: A review. J Hazardous Mater. 2020 Mar;386:121632, doi:10.1016/j.jhazmat.2019.121632

26. Al-Ghouti MA, Da'ana DA. Guidelines for the use and interpretation of adsorption isotherm models: A review. J of Hazardous Mater. 2020 Jul;393:122383, doi: 10.1016/j.jhazmat.2020.122383

27. Caivano J, Buera MDP. Color in food: Technological and psychophysical aspects. Boca Raton (FL): CRC Press; 2012.

28. MacDougall D. Colour in food. Boca Raton (FL): CRC Press; 2002.

29. Rojas MJ, Amaral-Fonseca, M Fernandez-Lafuente, Giordano, RLC, Tardioli PW. Recovery of starch from cassava bagasse for cyclodextrin production by sequential treatment with $\alpha$-amylase and cyclodextrin glycosyltransferase. Biocatalysis and Agri Biotech. 2019 Nov;22:101411, doi: 10.1016/j.bcab.2019.101411

30. Andrade-Mahecha MM, Pelissari FM, Tapia-Blácido DR, Menegalli FC. Achira as a source of biodegradable materials: Isolation and characterization of nanofibers. Carbohyd Polym. 2015 Jun;123:406-415, doi: 10.1016/j.carbpol.2015.01.027

31. Bhatnagar A, Sillanpää M. Utilization of agro-industrial and municipal waste materials as potential adsorbents for water treatment-A review. Chem Eng J. 2010 Mar;157(2-3):277-296, doi:10.1016/j.cej.2010.01.007 
32. Guin JP, Bhardwaj YK, Varshney L. Radiation grafting: A voyage from bio-waste corn husk to an efficient thermostable adsorbent. Carbohyd Polym. 2018 Mar;183:151-164, doi: 10.1016/j.carbpol.2017.11.101

33. Guimarães JL, Frollini E, Silva CG, Wypych F, Satyanarayana KG. Characterization of banana, sugarcane bagasse and sponge gourd fibers of Brazil. Indust Crops Prod. 2009 Nov;30(3):407-415, doi: 10.1016/j.indcrop.2009.07.013

34. Xie X, Xiong H, Zhang Y, Tong Z, Liao A, Qin Z. Preparation magnetic cassava residue microspheres and its application for $\mathrm{Cu}(\mathrm{II})$ adsorption. J of Environ Chem Eng. 2017 Jun;5(3):2800-2806, doi: 10.1016/j.jece.2017.05.024

35. Wiercigroch E, Szafraniec E, Czamara K, Pacia MZ, Majzner K, Kochan K, Kaczor A, Baranska M, Malek K. Raman and infrared spectroscopy of carbohydrates: A review. Spectrochimica Acta Part A: Molecular Biomolecular Spec. 2017 Oct;185:317-335, doi: 10.1016/j.saa.2017.05.045

36. Demiral H, Güngör C. Adsorption of copper(II) from aqueous solutions on activated carbon prepared from grape bagasse. J Clean Prod. 2016 Jun;124:103-113, doi: 10.1016/j.jclepro.2016.02.084

37. Yang H, Yan R, Chen H, Lee DH, Zheng C. Characteristics of hemicellulose, cellulose and lignin pyrolysis. Fuel 2007 Aug;86(12-13):1781-1788, doi: 10.1016/j.fuel.2006.12.013

38. Yang J, Qiu K. Preparation of activated carbons from walnut shells via vacuum chemical activation and their application for methylene blue removal. Chem Eng J. 2010 Nov;165(1):209-217, doi: 10.1016/j.cej.2010.09.019

39. Alimohammadi Z, Younesi H, Bahramifar N. Batch and column adsorption of reactive red 198 from textile industry effluent by microporous activated carbon developed from walnut shells. Waste Biomass Valoriz. 2016 Feb;7:1255-1270, doi: 10.1007/s12649-016-9506-4

40. Bouchelta C, Medjram MS, Bertrand O, Bellat J-P. Preparation and characterization of activated carbon from date stones by physical activation with steam. J Anal App Pyrolysis 2008 May;82(1):70-77, doi: 10.1016/j.jaap.2007.12.009

41. Zbair M, Bottlinger M, Ainassaari K, Ojala S, Stein O, Keiski RL, Bensitel M, Brahmi R. Hydrothermal carbonization of argan nut shell: Functional mesoporous carbon with excellent performance in the adsorption of bisphenol $A$ and diuron. Waste Biomass Valor. 2020 Dec.;11:1565-1584, doi: 10.1007/s12649-018-00554-0

42. Beakou BH, El Hassani K, Houssaini MA, Belbahloul M, Oukani E, Anouar A. Novel activated carbon from Manihot esculenta Crantz for removal of Methylene Blue. S Sustai Environ Res. 2017;27(5):215222, doi: 10.1016/j.serj.2017.06.003

43. Oliveira AVB, Rizzato TM, Barros BCB, Favaro SL, Caetano W, Hioka N, Batistela VR. Physicochemical modifications of sugarcane and cassava agro-industrial wastes for applications as biosorbents. Bioresour Technol Reports. 2019 Sep;7:100294, doi: 10.1016/j.biteb.2019.100294

44. Reck IM, Paixão RM, Bergamasco R, Vieira MF, Vieira AMS. Removal of tartrazine from aqueous solutions using adsorbents based on activated carbon and Moringa oleifera seeds. J Clean Prod. 2018 Jan;171:85-97, doi: 10.1016/j.jclepro.2017.09.237

45. Sahnoun S, Boutahala M. Adsorption removal of tartrazine by chitosan/polyaniline composite: Kinetics and equilibrium studies. Int $\mathrm{J}$ Biol Macromol. 2018 Jul;114:1345-1353, doi: 10.1016/j.ijbiomac.2018.02.146

46. Kooh MRR, Lim LBL, Dahri MK, Lim LH, Sarath Bandara, JMR. Azolla pinnata: An efficient low cost material for removal of methyl violet $2 \mathrm{~B}$ by using adsorption method. Waste Biomass Valor 2015 Apr;6:547-559, doi: 10.1007/s12649-015-9369-0

47. Banerjee S, Chattopadhyaya MC. Adsorption characteristics for the removal of a toxic dye, tartrazine from aqueous solutions by a low cost agricultural by-product. Arabian J Chem. 2017 Jun;10(Suppl 2):S1629-S1638, doi: 10.1016/j.arabjc.2013.06.005

48. Gautam RK, Gautam PK, Banerjee S, Rawat V, Soni S, Sharma SK, Chattopadhyaya MC. Removal of tartrazine by activated carbon biosorbents of Lantana camara: Kinetics, equilibrium modeling and spectroscopic analysis. J Environ Chem Eng. 2015 Mar;3(1):79-88, doi: 10.1016/j.jece.2014.11.026

49. Ghemit R, Makhloufi A, Djebri N, Flilissa A, Zerroual L, Boutahala M. Adsorptive removal of diclofenac and ibuprofen from aqueous solution by organobentonites: Study in single and binary systems. Groundwater for Sustai Dev. 2019;8:520-529, doi: 10.1016/j.gsd.2019.02.004

50. Mittal A, Kurup L, Mittal J. Freundlich and Langmuir adsorption isotherms and kinetics for the removal of Tartrazine from aqueous solutions using hen feathers. J of Hazardous Mater. 2007 Jul;146(1 -2):243248, doi: 10.1016/j.jhazmat.2006.12.012

51. Wan Ngah, WS, Teong LC, Hanafiah MAKM. Adsorption of dyes and heavy metal ions by chitosan composites: A review. Carbohyd Polym 2011 Feb;83(4):1446-1456, doi: 10.1016/j.carbpol.2010.11.004 
52. Goscianska J, Ciesielczyk F. Lanthanum enriched aminosilane-grafted mesoporous carbon material for efficient adsorption of tartrazine azo dye. Microporous and Mesoporous Mater. 2019 May;280:7-19, doi: 10.1016/j.micromeso.2019.01.033

53. Epstein J, Michael J, Mandona C, Marques F, Dias-Cabral AC, Thrash M. Modeling Langmuir isotherms with the Gillespie stochastic algorithm. J Chromatography A. 2015 Feb;1380:81-87, doi.org/10.1016/j.chroma.2014.12.059

54. Martini BK, Daniel TG, Corazza MZ, Carvalho, AE. Methyl orange and tartrazine yellow adsorption on activated carbon prepared from boiler residue: Kinetics, isotherms, thermodynamics studies and material characterization. J Environ Chem Eng. 2018 Oct;6(5):6669-6679, doi: 10.1016/j.jece.2018.10.013

55. Verma AK, Dash RR, Bhunia P. A review on chemical coagulation/flocculation technologies for removal of colour from textile wastewaters. J of Environ Management. 2012 Jan;93(1):154-168, doi: 10.1016/j.jenvman.2011.09.012

56. Karimifard S, Moghaddam MRA. Application of response surface methodology in physicochemical removal of dyes from wastewater: A critical review. Sci Total Environ. 2018 Nov; 640-641:772-797, doi: 10.1016/j.scitotenv.2018.05.355

57. Renault F, Sancey B, Badot P-M, Crini G. Chitosan for coagulation/flocculation processes - An ecofriendly approach. European Polym J. 2009 May;45(5):1337-1348, doi: 10.1016/j.eurpolymj.2008.12.027

58. Du Z, Zheng T, Wang P. Experimental and modelling studies on fixed bed adsorption for $\mathrm{Cu}(\mathrm{II})$ removal from aqueous solution by carboxyl modified jute fiber. Powder Technol 2018 Oct;338:952-959, doi: 10.1016/j.powtec.2018.06.015

59. Basu M, Guha AK, Ray L. Adsorption of lead on lentil husk in fixed bed column bioreactor. Bioresour Technol. 2019 Jul;283:86-95, doi: 10.1016/j.biortech.2019.02.133

60. Abdolali A, Ngo HH, Guo W, Zhou JL, Zhang J, Liang S, Chang SW, Nguyen DD, Liu Y. Application of a breakthrough biosorbent for removing heavy metals from synthetic and real wastewaters in a labscale continuous fixed-bed column. Bioresour Technol. 2017 Apr;229:78-87, doi: 10.1016/j.biortech.2017.01.016

61. Charola S, Yadav R, Das P, Maiti S. Fixed-bed adsorption of Reactive Orange 84 dye onto activated carbon prepared from empty cotton flower agro-waste. Sustai Environ Res. 2018 Nov;28(6):298-308, doi: 10.1016/j.serj.2018.09.003 


\section{Supplementary Material}

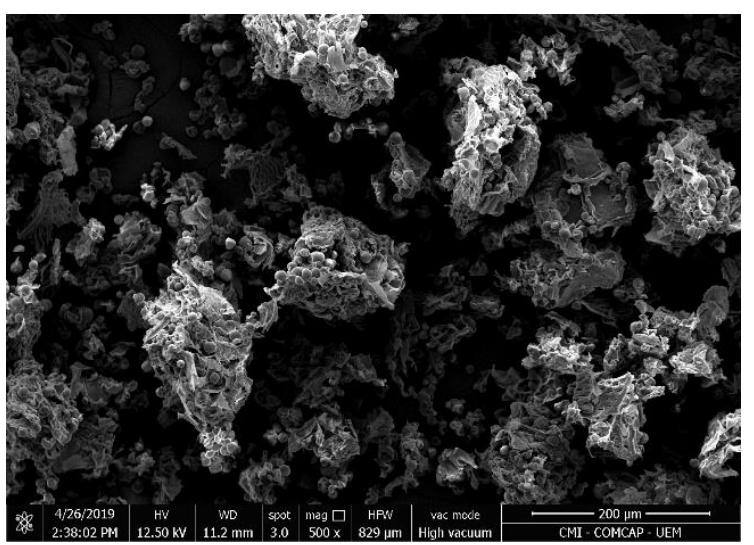

A

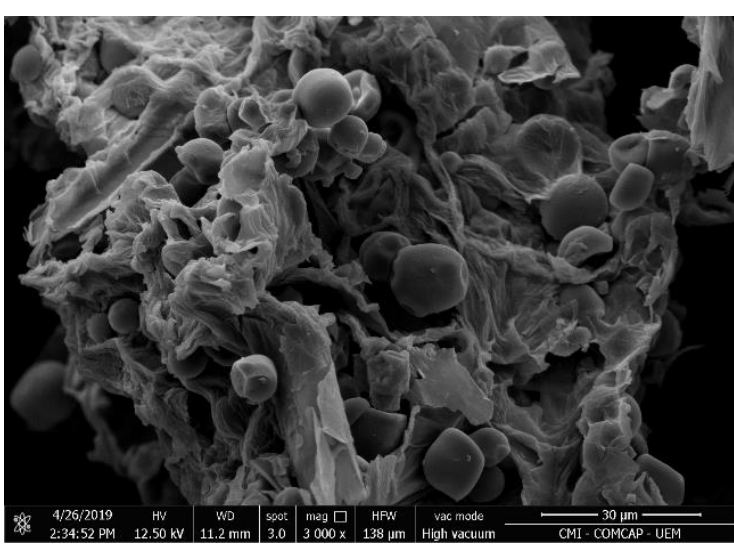

B

Figure S1: Micrographs of the CAW with 500x magnifications (A) and 3000x magnifications (B).

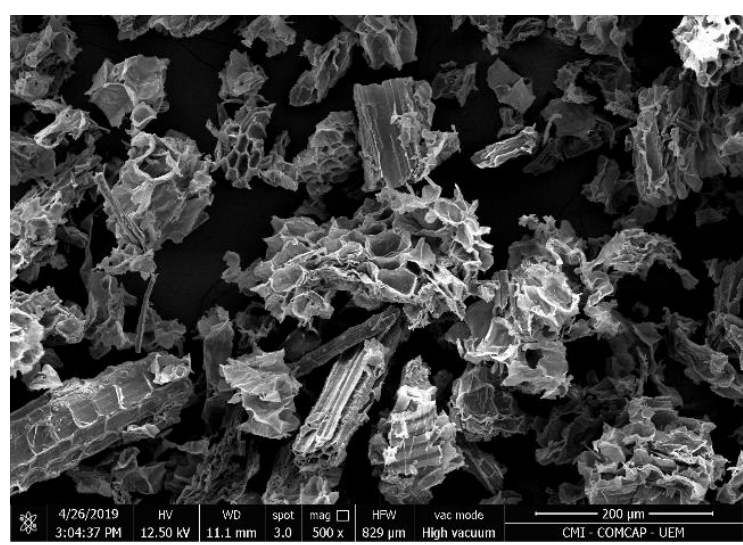

C

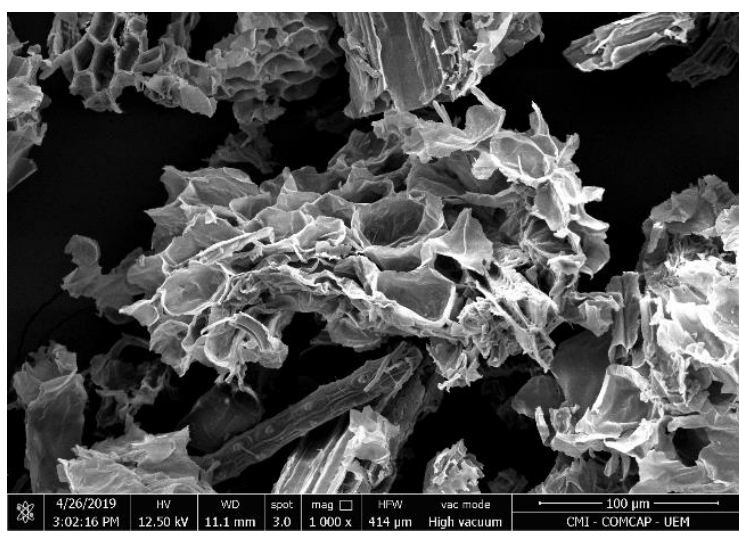

$\mathrm{D}$

Figure S2: Micrographs of the PPW with 500x magnifications $(C)$ and 1000x magnifications $(D)$. 